\title{
Corporate Volunteering: a Tool for Promoting a Strategy for Internal Corporate Social Responsibility Integrating Retirees
}

\author{
Voluntariado Corporativo como Herramienta de Promoción \\ de la Estrategia de Responsabilidad Social Corporativa \\ Interna Integrando Aposentados
}

Voluntariado Empresarial: uma Ferramenta para Promover a Estratégia de Responsabilidade Social Corporativa Interna

Integrando Aposentados

José Paulo Cosenza

María Isabel Saz Gil

Ana Isabel Zardoya Alegría

\begin{abstract}
This paper aims to make an exploratory analysis of the effectiveness of implementing a Corporate Volunteering program aimed at the context of retired workers, as a tool for participatory and healthy aging. The research study focused on the importance of the social participation of retirees in a company as a priority interest for the development of Corporate Volunteering programs, and delved into the expression of the socially responsible performance of organizations in volunteering actions carried out by their retired employees. Results show that the performance of retirees in a company's volunteering activities can count on intimately connected theoretical supports and is closely related to Corporate Social Responsibility, fostering an active, healthy and fair old age, with social benefit to the community.
\end{abstract}

Keywords: Corporate Volunteering; Corporate Social Responsibility; Volunteering Cycle. 
RESUMEN: Este artículo tiene como objetivo realizar un análisis exploratorio de la efectividad de implementarse de un programa de Voluntariado Corporativo dirigido al contexto de los trabajadores jubilados de las empresas, herramienta para el envejecimiento participativo y sano. El estudio se centró en la importancia social de la participación de los jubilados en una empresa como interés prioritario para el desarrollo de programas de Voluntariado Corporativo y para adentrarse igualmente en la expresión de la actuación socialmente responsable de la organización en acciones de voluntariado realizadas a través de la figura de sus empleados jubilados. Los resultados muestran que el aprovechamiento de los jubilados en las actividades voluntarias de la empresa se puede contar con soportes teóricos estrechamente conectados y se encuentra íntimamente relacionado con la Responsabilidad Social Empresarial, contribuyendo para construir un envejecimiento participativo por una vejez más saludable y justa, con beneficio social a la comunidad.

Palabras clave: Voluntariado Corporativo; Responsabilidad Social Empresarial; Ciclo del Voluntariado.

RESUMO: Este artigo tem como objetivo realizar uma análise exploratória da efetividade da implementação de um programa de Voluntariado Corporativo voltado ao contexto dos trabalhadores aposentados das empresas, como instrumento em prol de um envelhecimento participativo e saudável. O estudo centrou-se na importância social da participação social dos aposentados em uma empresa como interesse prioritário para o desenvolvimento de programas de Voluntariado Corporativo e aprofundamento do desempenho socialmente responsável das organizações, em ações de voluntariado realizadas por seus funcionários aposentados. Os resultados mostram que o desempenho dos aposentados nas atividades de voluntariado de uma empresa pode usufruir de suportes teóricos intimamente conectados e está diretamente relacionado à Responsabilidade Social Empresarial, contribuindo para promover uma velhice ativa, saudável e justa, com benefício social para a comunidade.

Palavras-chave: Voluntariado Empresarial; Responsabilidade Social Empresarial; Ciclo do Voluntariado. 


\section{Introduction}

Volunteering is any activity in which time is given freely to benefit another person, group, or organization, and, tradicionally, it has been an important component of civil society all over the world (Eller, 2013).

In the business field, the phenomenon of volunteering, the so-called Corporate Volunteering (hereinafter referred to as CV), can be considered as an element in CSR policies (Santos, \& Fernández, 2017).

According to Pevnaya and Kuzminchuk (2016), the approach of volunteering as Corporate Social Responsibility (hereinafter referred to as CSR) becomes a marketing tool and a leverage that affect the public image of the company, considering that $\mathrm{CV}$ has received extensive industry uptake ahead of empirical evidence supporting its potential benefits.

$\mathrm{CV}$ is most of the time one of the instruments deployed by companies within the scope of their CSR practices (Pevnaya, \& Kuzminchuk, 2016), and they are part of Internal Corporate Responsibility (Internal CSR), in addition to having a relevant influence on External Corporate Responsibility (External CSR). Therefore, these programs should be directed to the different internal stakeholders of the company, among which are, in addition to active workers, retired and pre-retired workers of the organization. In addition, CV programs constitute an institutional framework fostering volunteering for retired and early retirees and these groups can have a great influence on External CSR.

The two most important theoretical approaches to understanding the relationship between the practice of volunteering and the work situation have been the "Activity Theory" [argueing that the more active the aging process of the elderly is and the more social activities are carried out by them, the greater satisfaction they will obtain in their life] and the "Continuity Theory" [affirming that the past experiences of the elderly are connected with their activities, behaviors, personalities, and relationships in old age]. Thus people who get older, because they believe that old age is an extension of the previous evolutionary stages, are inclined to maintain as much as they can the same habits, abilities, personalities, behaviors and lifestyles that they developed in previous years. 
The hypothesis of substitution or activity theory (Cavan, et al., 1949; Cavan, 1962; Havignhurst, \& Albrecht, 1953; Havighurst, Neugarten, \& Tobin, 1963) is based on the premise that the substitution of activities helps maintain subjective and moral well-being (Herzog et al, 1989). According to the continuity theory (Atchley, 1971a; Atchley, 1971b; Maddox, 1963; Maddox, \& Douglas, 1973; Costa, \& McCrae, 1980), to preserve people's well-being throughout their life, it is important to maintain patterns of behavior previously established, especially in important transitions such as retirement (Atchley, 1993; Atchley, 1999).

The interest in the patterns of the use of the elderly's time is not new; since the $60 \mathrm{~s}$, many studies have been generated with the purpose of analyzing what "successful aging" consists of. Some of these studies have shown the relationship between patterns of time use and various indicators of well-being (Gauthier, \& Smeeding, 2003).

However, retirement means more than a cessation of work, as it can cause loss of income, social status, social relationships etc.

George (1980) identifies three personal resources that influence retirement adaptation: income (high income levels facilitate adaptation), health (good health increases well-being during retirement) and social support (for example, a positive marital relationship contributes to adaptation). King and Fluke (1990) show that working in today's society provides a sense of belonging or a feeling of being needed. Volunteering is an activity that fulfills much of the same job functions and additionally contributes to the community (Cohen-Mansfield, 1989). Paid work and volunteering differ in many aspects, but both activities involve productive contributions to society (Luoh, \& Herzog, 2002).

As pointed out by Dávila and Díaz-Morales (2009), volunteering has been conceptualized as a substitute for paid work or as a complement to it. In this sense, it is important to develop a favorable institutional volunteering framework, through the promotion of $\mathrm{CV}$, in the period of work activity and the performance of paid work, so that people can continue volunteering after retiring.

As a means to project CSR, CV allows organizations to link labor and social demands. $\mathrm{CV}$ is a recent study topic, intended to observe how volunteering work helps in the achievement of the company's objectives, to explore the different scenarios in which they are carried out, and to investigate whether greater integration has been achieved among the members of the organization improving interpersonal relationships (Bowman, 2012). 
This work aims to show the importance of the development of CV programs as a strategy to promote CSR and as an institutional framework for volunteering in people's retirement phase, and to examine the implications and impacts that $\mathrm{CV}$ programs generate within the concept of CSR, with a special interest in delineating its application to the context of the retired and preretired workers of an organization.

The study contributes to the discussion of the CV literature, focusing on the positive effects of the implementation of $\mathrm{CV}$ programs as a strategy to promote CSR and as an institutional framework for volunteering work at people's retirement stage.

The motivation for this paper is twofold: First, by providing knowledge about CV, a subject that is increasingly becoming a part of CSR, and that necessarily implies the establishment of management control mechanisms, especially by relating it to the companies' retired employee policy. Second, by submitting a proposal for stable integration between the company's social role and the CV programs. This helps us to discern what is the connection between CSR and CV as a practice to motivate retired employees toward a proactive life.

The structure of this paper is as follows. In Section 2, we present the theoretical framework of $\mathrm{CV}$. The focus is on the review of the literature about this subject.

In Section 3, we discuss "active aging" as an expression of a social need with priority interest from both political and socio-economic institutions. In Section 4, we describe CV as a necessary antecedent of CSR, commenting on the links between them and the expectations and demands generated by this link. In Section 5, we illustrate the purposes of the benefits of CV for retirees in terms of a more active, healthier and fairer aging, in line with contemporary humanitarian principles that pose older people as more than mere recipients of services and benefits. In the final section we present conclusions, followed by the references used in the research. Below, each of the above sections will be described in a deeper and more structured way.

\section{Conceptual Framework of Corporate Volunteering}

Traditionally, volunteering work has always been predominantly associated with acts of charity, and the vast majority associated with religious institutions. However, in recent years, volunteering has been taking on new designs in its working ways, a fact that demands more 
attention and encouragement from governments, companies, nonprofit organizations and from people individually. Although volunteering plays a prominent role in the charitable provision of goods and services, there is still a lack in this area, because evidences show there is little or incomplete understanding of why people supply labor seemingly for free (Carpenter, \& Myers, 2007).

According to Souza (2008), volunteering work, which was previously linked mainly to Christian charity, is currently secularized and linked to business initiatives and citizenship actions. This trend began in the United States, in the 1970s, when a particular type of volunteering work associated with CSR emerged.

This form of volunteering work consisted especifically of social actions developed by virtue of a business initiative. In it, in general, employee volunteering work of those companies or even of the wider community were mobilized, with or without direct financial support from the sponsoring company. According to Ibáñez (2013), in this new business configuration, volunteering has ceased to be mere philanthropy, and has become a usual action that the company takes in its own operation.

Since then, one of the great aspects of volunteering work has been conducted by companies that, motivated by the challenge of CSR and stimulated not only by the country's legislation but also by various global movements, take on the responsibility to increase efforts for a better world. They aim to develop their staff satisfaction in participating in an organization that supports and encourages the implementation of volunteering work programs and projects (Lima, \& Bareli, 2011).

Thus companies have been increasingly investing in social actions, not only for the growing awareness or force of law, but also for differentiation and competitiveness in their markets, with a greater commitment of their employees.

Within the past decades, CV programs have emerged as a core component of business social responsibility initiatives. In this context, CV emerges as a new trend in the context of CSR policies implemented by companies, especially the large ones. Albeit very important and significant, among the characteristics that define the CV programs are the ones that generate impact on the different stakeholders, in special the participation of the company and its employees. Therefore, it is required a high level of planning and coordination among all parties involved. 
Burnes and Gonyea (2005) point out that CV actions are framed as an important tool within CSR, constituting one of the facets to demonstrate the commitment of companies with the development of society and sustainability (Guerra, 2013).

Hence, CV motivates companies as an attempt to gain legitimacy (Di Maggio, \& Powel, 1983) before society (Pelloza, \& Hassay, 2006; Basil, et al., 2009), through actions and behaviors aimed at maintaining a behavior incentive system and results based on competences implicit in power structures and mental models (Vargas, 2006).

However, Guerra (2013) points out that CV is also conceptually supported in other theoretical frameworks, such as the Theory of the Organization (Simon, 1962); the Agency Theory (Bairman, 1984); the Theory of Resources and Capabilities (Penrose, 1959; Rumelt, 1984; Grant, 1996; Porter, 1980), and the Stakeholder Theory (Freeman, 2010). All these theoretical approaches, according to Guerra (2013), offer methodological support that allows the design of a comprehensive conceptual framework for $\mathrm{CV}$, capable of encompassing the different perspectives that exist within an organization.

In Figure 1, we graphically represent this conjunction of theoretical approaches capable of linking CV in the company's performance in terms of CSR. 
Figure 1 - The theoretical framework of corporate volunteering

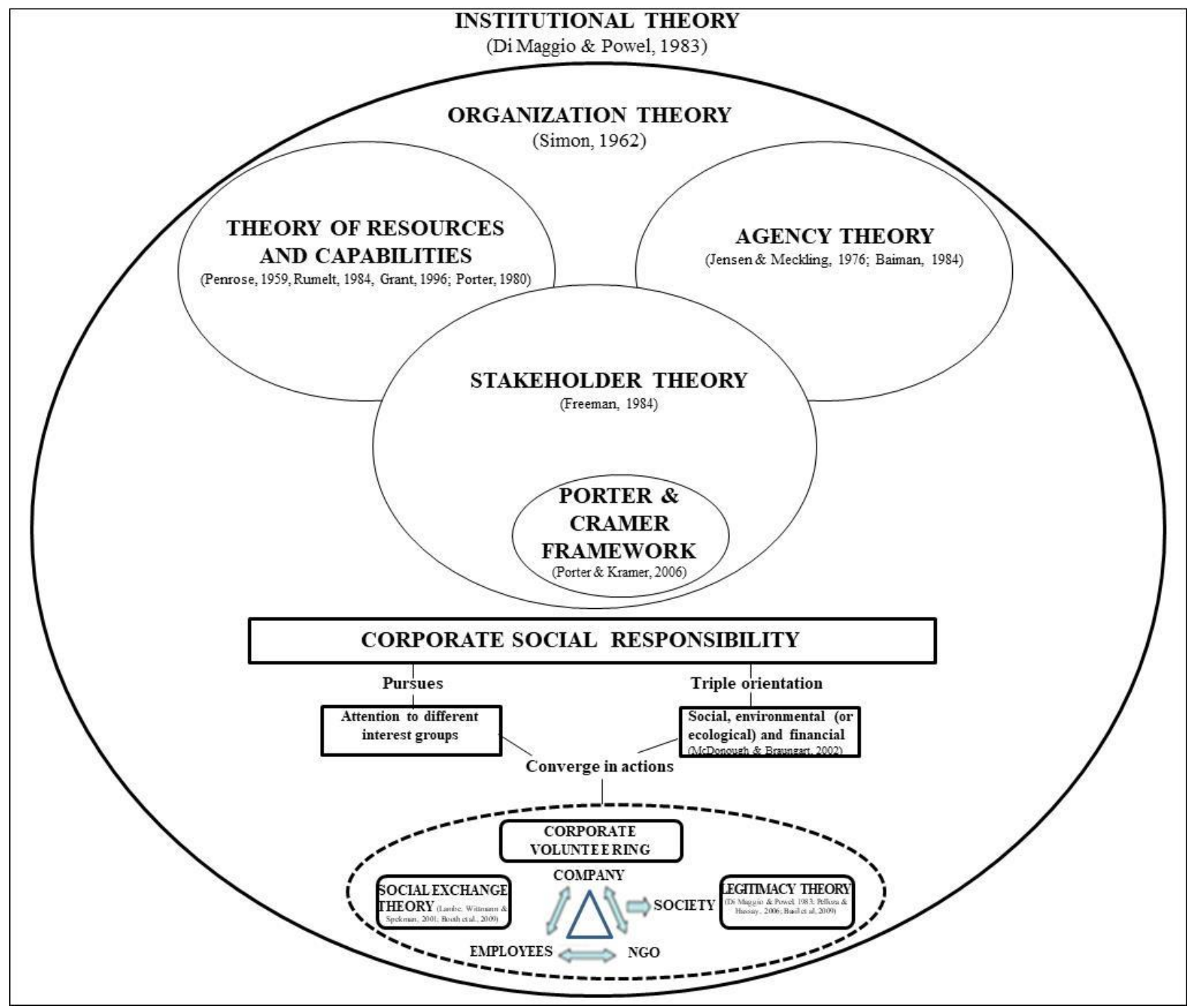

Source: Own elaboration, based on Gallardo, et al. (2010), Guerra (2013), and Sanchez and Gallardo (2013)

As a starting point, we will cite the Institutional Theory (Di Maggio, \& Powel, 1983), which states that institutions represent the rules of the game played by companies, which ends up entailing them to build their actions seeking to legitimize the values desired by the institutions that are key to society. Thus the conduct of the company is represented by the establishment and dissemination of norms of action necessary to reach business legitimacy. 
Furthermore, the Theory of the Organization (Simon, 1947) enables a method of systemic business approach to support CV. Partly because this approach sees the company as a multifaceted reality divided into different dimensions, allowing an analysis in different magnitudes, including its surroundings, but with a vision of the whole, besides giving the human factor the leading role of the organization.

According to Guerra (2013), "this theory supports CV in that it conceives the company as a systemic organization, that is, open to society and with the human factor at the center of its actions".

Based on the Agency Theory (Baiman, 1984), which is set on the existence of asymmetric information and interests in the company, studies have been carried out to minimize the agency costs existing in the company, by increasing its social legitimacy. Faced with this, CV emerges as a mechanism to legitimize the company's actions to eliminate its agency costs. According to Vargas (2013), the goal is to achieve or increase the legitimacy of the company visà-vis society as a whole, for which CV plays the role of reducing agency costs in the company.

On the other hand, the Theory of Resources and Capacities (Penrose, 1959) postulates that the intrasectorial differences due to the resources and capacities of each company generate different results between them (Rumelt, 1984). Along this line, CV allows us to approach strategies that will lead to better performances, especially in relation to the company's employees, since there is generation of competitive advantages by contributing to the development of their capacities (Gallardo, et al., 2010).

The Stakeholder Theory (Freeman, 2010), linked to CSR, establishes that the company should also meet the demands of the different interest groups linked to it: that is, not only the shareholders, customers and suppliers, but also the employees and society that are often the ultimate beneficiaries of the effects of the CV practiced (Guerra, 2013).

Along the same line, the Social Exchange Theory views relations as a social behavior that may result in economic and social outcomes. Therefore, a company is socially responsible when it has in its strategic planning, objectives and strategies directed to the economic, social and environmental aspects (Lambe, Wittmann, \& Spekman, 2001; Booth, et al., 2009). This is the perspective of the triple bottom line that links the company's objectives in three dimensions: economic, social and environmental (McDonough, \& Braungart, 2002). 
Under this approach, the CSR conceptual model proposed by Porter and Kramer (2006) assigns CV a strategic nature for the company in its chain of competitive value in its social and environmental performance.

The foundations of the Legitimacy Theory (Di Maggio, \& Powel, 1983) are summarized in that the environment offers a vision of how organizations should behave and act, which must follow a set of rules, more or less specified, and through the fulfillment of these norms, the environment and stakeholders approve of the entity socially. Not only are financial results required but also compliance with a set of general rules of behavior. It is about the organization's capture of a more environmental resource: social legitimacy (Scott, 1992).

The environment rewards the organization not only for the way it supplies goods and services, but also for adapting to the values, norms and beliefs of society.

Similarly, social exchange theory is also the starting point for $\mathrm{CV}$, so companies can channel their social responsibility actions through Non-Governmental Organizations (NGOs) or Non-Profit Organizations (NPOs) and these benefit from the company getting volunteers.

We have moved from an environment where there was scarcely any objective other than the remuneration of shareholders through dividends and they were practically the only ones the financial information of the company was directed to, to another in which there are several agents involved and interested in its activity. CV has to be implemented at a strategic level, because it renders the company socially responsible and also because it can achieve a true motivation in the area of human resources, which is very difficult to do many times by traditional methods of management control (Lima, \& Bareli, 2011; Rosenfeld, et al., 2011; Piacentini, 2015; Souza, 2008).

Therefore, CV programs are a strategy within the concept of CSR, and are part of the Internal CSR, in addition to its significant influence on the External CSR. Thus these programs should be directed to the different internal stakeholders of the company, among which are, in addition to the active workers, the retired and pre-retired workers of the organization.

In addition, $\mathrm{CV}$ programs constitute an institutional framework favorable to volunteering for retired and pre-retired people and these groups can have a great influence on the External CSR.

Bowman (2012) describes CV as an approach within the CSR aimed at involving the intellectual capital of the organization in relation to the community. 
Employees participate in activities outside their usual tasks, contributing to social needs which do not generate External CSR revenue for the company but add benefits for the community through non-profit organizations in which they contribute their talent. CSR is considered a proactive attitude to harmonize social objectives with tangible benefits in companies that show a greater real commitment to their social and environmental responsibilities (Briseño, Lavín, \& García, 2011).

\section{Life After Work is a Social Problem}

The world's population is aging and in the near future the specific weight of senior citizens for society will become significantly bigger than the weight of the young ones. According to Ferreira (2015, p. 10), "the problem that aging poses to society as a whole comes down to the place old age has in society and the refusal to exclude the elderly from social life, defining old age as a social condition of dependency".

This reflects a reality that shows an incipient social need, since the greater participation of older people will need to be highlighted as a priority interest both $\mathrm{f}$ om a political and a socioeconomic perspective.

One of the factors that has led to the lengthening of human life is mainly the widespread decline in birth rates and infant mortality rates. Also, the improvement of people's standard of living in general implies benefits with the health and the maintenance of a more active and healthy life. However, a longer life implies new social problems because "the increase in the demand for social services and health for this population will in turn require the improvement of the supply of exisiting conditions that already exist and, above all, the contribution of new creative solutions that monetize the resources available" (Calero, et al., 1996).

Retirement is a stage of human life where one has to get prepared to consolidate projects that grant them well-being and the achievement of clear personal aims (Iacub, et al., 2015: 88).

Thus social support is a sine qua non for the well-being of the seniors (Freixas, 1993), and for that, it seems that taking advantage of the contribution of unemployed seniors (in particular, retirees) who enjoy good health is an imaginative solution to integrate older people by motivating them to a more active life (Calero, et al., 1996). 
For Roca and Llarguer (1994), supporting them may be of maximum social interest if it is regulated and formalized. In this respect, $\mathrm{CV}$ is perceived in a very favorable way to add wellbeing to the elderly and to lead them socially toward a more active and participative postemployment life.

Nevertheless, the ideal of "senior volunteer" is still a minority aspect since passivity is common in the population already retired. According to Gonyean and Googins (2006), the lower rates of volunteering work among older people are often explained by the loss of social connections in their lives, such as retirement from the workforce. Although it can be verified the little development of senior volunteering, it is increasing the number of older people who at the moment are motivated to devote their time to that type of activity. In the United States, older volunteers are more likely than younger volunteers to work primarily for religious organizations; almost half (42.7 percent) of volunteers are 65 years of age and over (compared with 25.4 percent of volunteers aged 16 to 24) and older volunteers served mainly through or for a religious organization (Bureau of Labor Statistics, 2015).

Still, notwithstanding this visible increase of volunteering in the world, few are the older volunteers who participate beyond the threshold of their home (Agulló, Agulló, \& Rodríguez, 2002). In fact, the growth of CV programs is real, but this rapid growth does not imply the incorporation of retired employees nor does it offer opportunities for them in the volunteering programs of their companies. According to Walker Information (2003), despite the dramatic growth in the number of companies offering volunteering programs, the percentage of employees participating in these programs has remained relatively stable.

To Gonyea and Googins (2006), the two primary reasons offered for the expansion of volunteering programs not having produced more volunteers are the lack of resources and the lack of strategic management.

Companies play an important role in this issue if they focus on volunteering. This will necessarily not only translate into the allocation of resources to $\mathrm{CV}$ programs but also think strategically in terms of promoting opportunities to retired employees as untapped assets.

From the business strategies perspective, companies need to develop programs to volunteers that include opportunities for retired employees in these activities, addressing the realities of the aging of the labor force, including changing opinions about retirement. 
To AARP (1997), despite the alarms raised in recent years in relation to people's lack of interest and engagement in getting involved and participating in the problems of civil society, a new vision on retirement proposes voluntary practices in the social adult age (Guterbock, \& Fries, 1997). This includes an interest in remaining in the labor force, a desire for jobs with a sense of purpose, an attraction to opportunities that benefit or help the community, and a greater sense of fluidity among work, retirement and volunteering - suggesting that the workplace represents an important arena for mobilizing and tapping into the rich resources or social capital of this generation (Gonyea, \& Googins, 2006).

However, this activity requires more than the simple disposition of the involved parties (NGOs, companies, intermediaries, etc.), since to obtain benefits of volunteering it is necessary to dedicate effort, means and resources in an organized way through correct volunteering management by all the parties involved (Moreno, 2013).

\section{Relationship of Retirees with Corporate Volunteering}

Many people consider that the drop in productive or labor activity will save them time to enjoy life, spending hours imagining what they will do throughout retirement. In general, there is a belief that retirement is the beginning of enjoyable life, like a theater marquee enriched with the words: "next premiere, new life" (Guerra, 2016). On the other hand, other people do not even want to retire because they cannot conceive what they will do after finishing their working life. The fear of those pre-retired people is that the lack of the daily routine carried out for several consecutive years will render their lives emotionless or senseless and end up pushing them to a deep state of depression or sadness.

Sociological research on people's behavior after termination of their working life (see Lawson, 1993), in the United States, the United Kingdom and Spain, indicates differences between retirees and "active" retirees [the ones who decide to devote part of their time to volunteering] and "passive" [those who only dedicate themselves to "living their lives" in recreational activities, trips or rest].

Findings from some of these studies reveal that retired people who have active aging as a central issue tend to live longer than those who prefer greater passivity in retirement. 
Similarly, although CV is increasingly present as a trend in vogue worldwide, to associate it with the issue of retirement is to express a social need as active aging directly involves concerns with health, social relations and independence at the same time that provides a more participative, healthy and less dependent old age. According to Agulló and Rodríguez (2002), the practice of senior volunteering can also mean a better physical and psycho-social health situation, implying advantages such as greater self-esteem and sense of usefulness, as well as an active, participatory and healthy aging.

However, even if these two visions on how to enjoy retirement are valid and the option for one or the other always involves a decision of a personal nature, it would be important to motivate and support employees regarding behavior after finishing their working life, stimulating them to devote part of their time to volunteering.

Nevertheless, it must be recognized that there are still few companies that include human resources policies aimed at their pre-retirees or retirees in their CV program. But there is the following question: is it more convenient for any person to volunteer once retired or start doing it during their active work life? For Vargas (2016), it would be quite beneficial for companies to encourage their employees in their active work life to be initiated in the "life" of volunteering.

Thus the fact that the association of the themes of retirement and volunteering at first glance seems to be a contradiction, at the same time as it constitutes antagonistic concepts (proactivity vs. passivity), there is a common denominator between both of them represented by the search for a better quality of life. The volunteering work carried out by older people who participate outside the domestic sphere implies giving them an active aging while contributing to a better well-being of the population that is covered by this type of dedication.

Although senior volunteering work can be carried out in different types (cultural volunteering, volunteering care, social volunteering, parish volunteering, informal neighborhood volunteering, economic volunteering, etc.), in this study, we will refer to the perspective of retirement from the frame of belonging to some type of organization or association sponsored by a public or private company. 


\section{Corporate Volunteering as a Background to Corporate Social Responsibility}

However, current and future retirees represent an important and largely untapped resource to corporations as they seek to tackle social and environmental problems in the local communities where they operate. Indeed, according to Gonyea and Googins (2006), investing in recruitment of retirees offers many businesses the opportunity to expand the boundaries of their corporate volunteering efforts.

In addition to the growth of the aging population in the next several decades, three other significant trends suggest why promoting inclusion of retirees in corporate volunteering programs is both important and timely: i) the emergence of the workplace as a community; ii) new views on retirement; and iii) the dramatic growth of volunteering programs in firms (Gonyea, \& Googins, 2006).

The concept of CSR has become fashionable in recent decades and although there are considerable examples of contributions and advances in the social and environmental field, there is still no consensus as to how this concept should be put into practice. Briseño, Lavín and García (2011) point out that there is a dichotomy of the relevant aspects of CSR since there is no common concept regarding the social behavior of companies and the basic components that characterize a socially responsible company, that is, the one that fulfills its social and environmental responsibilities. In many of the attributes proposed in the CSR concepts, there are elements common to all stakeholders related to the company (employees, local communities, suppliers, creditors and government).

In particular, it is important to highlight the constant concern that a company should have to improve the welfare of the community where it operates; and for that matter, social and environmental activities help achieve this goal. That is why this study advocates the inclusion of $\mathrm{CV}$ as an action that leads to the generation of CSR and also meets the demands of companies' stakeholders that are retirees and pre-retiree employees.

According to Hambach (2012) and Boris (2011), the involvement of companies in the community through practices of CSR has been identified as a significant factor in the volunteering practice infrastructure; however, Krasnopolskaya, Roza and Meijs (2016) allude that, until now, no empirical tests have assessed the potential of $\mathrm{CV}$ to provide such 
infrastructure. This question is particularly interesting, given that $\mathrm{CV}$ has been identified as the most common CSR practice, at least for multinational companies (see Basil, et al., 2009).

$\mathrm{CV}$ as a practice of CSR aids companies by strengthening employee satisfaction and retention internally and by strengthening corporate reputations and connections with stakeholders externally (Cycyota, Ferrante, \& Schroeder, 2016). This fact was confirmed in the research by Cycyota, Ferrante, and Schroeder (2016), whose findings suggest that many companies specifically link employee volunteering to their CSR strategy and also utilize similar practices to encourage and support their employee volunteering work.

There is increasing evidence in the world that employee volunteering programs have integrated their volunteering activities as part of the drive towards companies' CSR (Waikayi, Fearon, Morris, \& McLaughlin, 2012). In fact, the connection between CV and CSR is reported on firms' websites, in their annual report, and in sustainability reports, where organizations are using volunteering to demonstrate altruistic endeavors, giving away time for the good of others and society (Lantos, 2001, 2002).

Although there is much controversy about the discourse of companies that say they are behaving in a socially responsible manner, there is strong evidence that $\mathrm{CV}$ is used for legitimacy of the social role of these companies (Lantos, 2001; Bart, et al., 2009). The support to employee volunteering practices in local communities is an important corporate goal and is part of a company's CSR. Because of this, much volunteering research has shown that companies are increasingly adopting CV programs as a form of CSR. Furthermore, Pérez, et al. (2014) identify employees' learning experiences from $\mathrm{CV}$ as a key boundary condition of the relationship between $\mathrm{CV}$ and job performance.

Traditionally, the conceptual framework of CSR has been based on the scope of social responsibility from the perspective of outsourcing of sustainable development by focusing on aspects and variables outside the corporate activity, that is, External CSR. Nevertheless, a relatively new concept is now presented in the business context which, according to AECA (2016), brings together in a single term the most unknown and possibly worst-managed part of CSR: Internal CSR.

Internal CSR is defined as "the set of actions of a voluntary nature, whether economic, social or environmental, that have their focus of attention on the internal scope of the organization, but whose effect is determinant in the satisfaction of external agents and, therefore, 
in the external responsibility of the entity" (AECA, 2016). As a result, it can be said that such economic, social and environmental concerns are those in which relationships with the organization's internal stakeholders are observed and with an indirect but potentially determining effect on external stakeholders as an integral part of CSR.

Thus the CSR approach from the internal level of the organization involves confronting both the internal and external business environment, with the common goal of achieving the growth of companies in a responsible way.

It is a question of pointing out the link between internal actions that promote responsibility and external actions with society. Therefore, Internal CSR demands responsible management of the group of internal stakeholders, where employees or outsourced employees are included.

According to AECA (2016), the responsible management of employees can contribute positively to the implementation of Internal CSR, bringing them closer to the role of prescribers of the responsibility of the entity in which they work, even being able to convert them into true social intra-entrepreneurs, if they have the capacities, the necessary conditions and if they wish to develop them.

Along this line, conditions should be created to enhance the involvement and commitment of employees to participate as CSR prescribers, even willing to become involved, and invest time and effort in social activities, as active agents. CSR has been extensively treated in recent years, and CV programs are closely linked to Internal CSR, in addition to being considered key elements.

The employee involved in a CV action or program can help the company take a path that leads to a responsible and sustainable action and be perceived as an entity committed to society and the environment. With special interest in the delineation of the application of volunteering programs to the context of the retirees and pre-retiree workers of the organization, in Figure 2 we present a global view that shows the importance of the development of volunteering activities as a strategy to promote social responsibility and as an institutional framework for volunteering at people's retirement stage. This integrated approach allows both Internal CSR and External CSR to be closely related to the CV program as part of CSR. 
Figure 2 - Corporate volunteering relations with social responsibility

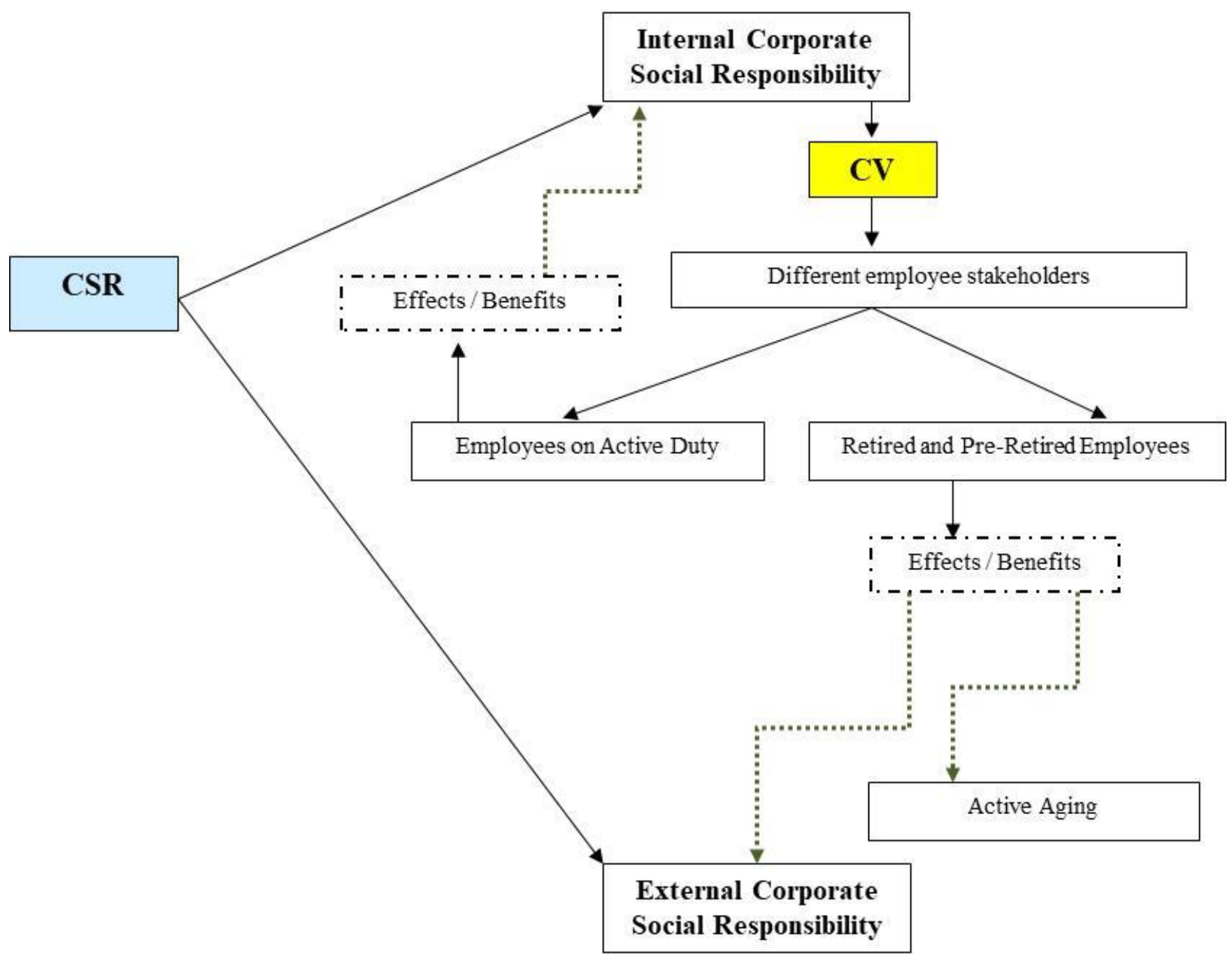

Source: Own elaboration

\section{Benefits Derived from Corporate Volunteering Applied to Retirees}

Many firms have demonstrated their CSR practices by promoting and engaging activities and events in local communities and public environment. 
Employee volunteering has been a great benefit for the companies when formal $\mathrm{CV}$ programs are strategically developed and implemented (Peloza, \& Hassay, 2006). A formal employee volunteering program is a citical and systematic effort on the part of an organization to create a structured approach to promoting the inclusion of their employees to serve the community and meet personal needs (social and philanthropic) deemed important for them (Luo, \& Bhattacharya, 2006).

The researchers have demonstrated that involvement in volunteering activities is particularly productive and has important societal and individual benefits for senior people in the current active aging context.

However, to Warburton, Paynter and Petriwsky (2007), little attention has been paid to the factors that encourage or discourage older people regarding the exercise of volunteering as a healthy activity. For these authors, one important dimension of a new social focus based on the change of dependence, frailty and poor health toward a healthy and productive aging approach relates to older people's contributions to society as volunteers.

The volunteering activity developed by older people could have important implications for a healthy and vibrant civil society. According to Greenfield and Marks (2004), and Lum and Lightfoot (2005), volunteering can be a positively productive aging activity that is also linked to a range of individual health and social benefits. To Musick and Wilson (2003) and van Willigen (2000), positive health outcomes include greater satisfaction and well-being in the later life, good health and better-perceived health, and reduced mortality rate. However, the strategic benefits of a volunteering program to retired employees have not been researched yet, but the positive impact that this type of volunteering could have on an organization's workforce is fully understandable.

Often the thought of retiring creates more stress for a retired employee than working through their busiest working days. Retirement is, at first sight, an uncertainty, considering that many factors involved in the subject are out of employers' control, including health status, what to do on their retirement days, and whether they will outlive after having led their lives in an office for a large number of years. Lack of control is especially difficult for retired employees, when they do not have any concrete plan on how they will spend their time once they retire. 
In relation to the concept of $\mathrm{CV}$, analyzing and evaluating the activity and productivity of the elderly is a complex issue and can be approached from different and varied facets in the field of retirement (Agulló, Agulló, \& Rodríguez, 2002). However, in general terms, voluntary activities by retirees or pre-retirees reflect greater satisfaction (social and self-satisfaction) on the part of those who carry them out, thus motivating them to a better adaptation to aging and building a more participatory, healthier and fairer age. For Agulló, Agulló and Rodríguez (2002), $\mathrm{CV}$ is positive as a practice for retirees because it helps to bridge that personal or social "gap" that the process of retirement or disconnection sometimes creates.

What is relevant is that $\mathrm{CV}$ is confirmed as an effective CSR tool in multiple aspects since its effects produce improvements to the environment where the company operates, benefiting especially its volunteer staff, the local community and society in general. It is for this reason that $\mathrm{CV}$ should be practiced with strategic perception oriented towards greater business competitiveness and improvement of the chain of value to the company in the long term.

The application of a corporate policy that explores more deeply the development of $\mathrm{CV}$ programs in companies as a complementary part of the search for the active aging of retired and pre-retired employees is considered a relevant factor when it comes to CSR practice.

\section{Final Reflections}

The contemporary way of life must include all the socialized, systematic and necessary activity that allows to actively link future generations of the elderly, so that psychological wellbeing is reflected in their mood and consequently in their desire to enjoy the years to come. It has already been proven that being integrated by means of social activities, in a systematic and organized way, carried out in a favorable way for good psychobiological regulation and within parameters well estimated by society and the individual, should favor health, longevity and happiness, whose achievement contributes to a happy, healthy and spiritually fulfilling old age.

In this study, it is offered a theoretical approach to understanding the under-researched area of CV as support for CSR. The paper explored the structural dimension of CV in relation to the incentives for the integration of retired employees and the barriers to volunteering as a key productive aging activity. 
Considering the lack of association of $\mathrm{CV}$ programs with the focus on retired employees, this paper explored the potential of volunteering to motivate older employees to integrate retiree volunteering activities as part of the drive towards companies' CSR.

With this study, we contribute to the theme of volunteering for the elderly, through the evidence that older people are able to contribute to $\mathrm{CV}$ programs and CSR, since they can also create added value. For that, we must draw a panoramic view on the issue of active aging as an expression of a social need rather than just a tendency that considers the elderly as passive entities and simple recipients of services and benefits.

Based on the postulates that support CV and CSR, in this study we discuss how CV policies might help senior people in the active and healthy aging context. However, despite the positive impact that this type of volunteering can have on an organization's workforce, the strategic benefits of a volunteering program to retired employees have not yet been thoroughly researched in the economic literature.

This study, when referring to $\mathrm{CV}$ strategies, indicates that the inclusion of retired employees in $\mathrm{CV}$ programs can produce an intergenerational relationship aimed at maintaining social care services aimed at the whole society and not only at the elderly segment.

It is noteworthy that the participatory aging approach presented in this paper is in line with the principles of the United Nations in favor of the elderly (UN, 1991 and 2002), corroborating the stance that older people are more than just simple recipients of services and benefits; On the contrary, we propose to consider them as active subjects that create and add value for companies and the society.

As for future research purposes, we point out that this work could be expanded with studies that deepen the knowledge of key variables, to motivate retirees and attract them to participate in senior $\mathrm{CV}$ programs in companies.

\section{References}

AARP. (1997). AARP Survey on Civic Involvement (Summary). Washington, DC: American Association of Retired Persons. Retrieved from: https://www.learningtogive.org/sites/default/ files/handouts/AARP_Survey_on_Civic_Involvement.pdf. Accessed June 27, 2017.

AARP. (2003). Staying ahead of the curve 2003: the AARP working in retirement study. Washington, DC: American Association of Retired Persons. Retrieved from: https://assets.aarp.org/rgcenter/econ/ multiwork_2003.pdf. Accessed June 27, 2017. 
AECA. (2016). Responsabilidad social corporativa interna. Delimitación conceptual $e$ información. [Documentos AECA, serie responsabilidad social corporativa].

Agulló Thomás, M. S., Agulló Thomás, E., and Rodríguez Suárez, J. (2002). Voluntariado de mayores: ejemplo de envejecimiento participativo y satisfactorio. Revista Interuniversitaria de Formación de Profesorado, 45, 107-128. Retrieved from: http://www.redalyc.org/pdf/274/ 27404509.pdf. Accessed June 27, 2017.

Allen, K. (2012). La gran carpa: Voluntariado corporativo en la era global. Madrid, España: Editorial Ariel.

Atchley, R. C. (1999). Continuity and adaptation in aging: creating positive experiences. Baltimore, USA: Johns Hopkins University Press.

Atchley, R. C. (1993). Continuity theory and the evolution of activity in later adulthood. In: Kelly, J. R. (Ed.). Activity and aging: Staying involved in later life. Newbury Park: Sage, 5-16.

Atchley, R. (1995). Age grading and grouping. In: Maddox, G. L. (Ed.). The encyclopedia of aging: A comprehensive resource in gerontology and geriatrics. (2nd ed.). New York, USA: Springer.

Atchley, R. C. (1971a). Retirement and leisure participation: continuity or crisis? The Gerontologist, 11(1), 13-17. Retrieved from: https://www.ncbi.nlm.nih.gov/pubmed/5579223. Accessed June 27, 2017.

Atchley, R. C. (1971b). Retirement and Work orientation. The Gerontologist, 11(1), 29-32. Retrieved from: https://doi.org/10.1093/geront/11.1_Part_1.29. Accessed June 27, 2017.

Baiman. S. (1982). Agency Research in Managerial Accounting: A Survey. Journal of Accounting Literature, 1, 154-213. Retrieved from: https://doi.org/10.1016/03613682(90)90023-N. Accessed June 27, 2017.

Bart, C.., Baetz, M. C., and Pancer, S. M. (2009). Leveraging human capital through an employee volunteer program: the case of Ford Motor Company of Canada. Journal of Intellectual Capital, 10(1), 121-134. Retrieved from: https://doi.org/10.1108/14691930910922941. Accessed June 27, 2017.

Basil, D. Z., Runte, M. S., Easwaramoorthy, M., and Barr, C. (2009). Company support for employee volunteering: a national survey of companies in Canada. Journal of Business Ethics, 85, 387-398. Retrieved from: http://dx.doi.org/10.1007/s10551-008-9741-0. Accessed June 27, 2017.

Booth, J. E., Won Park, K., y Glomb, T. M. (2009). Employer-supported volunteering benefits: gift exchange among employers, employees, and volunteer organizations. Human Resource Management, 48(2), 227-249. Retrieved from: https://doi.org/10.1002/hrm.20277. Accessed June 27, 2017.

Boris, E. (2011). [Ed.]. Study on nonprofit and philanthropic infrastructure. Boston, USA: Nonprofit Quarterly.

Cosenza, J. P., Gil, M. I. S., \& Alegría, A. I. Z. (2018). Corporate Volunteering: a Tool for Promoting a Strategy for Internal Corporate Social Responsibility Integrating Retirees. Revista Kairós-Gerontologia, 21(4), 161-189. Print ISSN $1516-2567$. ISSNe 2176-901X. São Paulo (SP), Brasil: FACHS/NEPE/PEPGG/PUC-SP 
Bowman, A. (2012). VC para el desarrollo: Una multiherramienta estratégica. Cómo hacer del Voluntariado Corporativo para el Desarrollo una herramienta universal para integrar empresa, empleados y desarrollo. In: Fundación CODESPA (Coord.). Voluntariado corporativo para el desarrollo: Una herramienta estratégica para integrar empresa y empleados en la lucha contra la pobreza. Madrid, España: Edición CODESPA, 33-41.

Briseño García, A., Lavín Verástegui, J., and García Fernández, F. (2011). Exploratory analysis of corporate social responsibility and its dichotomy in the business's social and environmental activities. Contaduría y Administración, 233, 73-83. Retrieved from: http://www.redalyc.org/pdf/395/39515424005.pdf. Accessed June 27, 2017.

Bureau of Labor Statistics. (2016). Volunteering in the United States, 2015. U.S. Department of Labor. Retrieved from: https://www.bls.gov/news.release/pdf/volun.pdf. Accessed May 21, 2017.

Burnes, K., and Gonyea, J. G. (2005). Expanding the boundaries of corporate volunteerism: retirees as a valuable resource. Boston, USA: Boston College Center for Corporate Citizenship.

Calero, M. D., García-Berben, T. M., Gálvez, M., Toral, I., and Bailón, R. (1996). Valoración de un programa de autoayuda entre ancianos: perfil de los voluntarios. Intervención Psicosocial, 5(13), 85-95. Retrieved from: http://www.copmadrid.org/webcopm/publicaciones/social/1996/ vol1/arti8.htm. Accessed May 23, 2017.

Carpenter, J., and Myers, C. K. (2007). Why Volunteer? Evidence on the Role of Altruism, Reputation, and Incentives. [Discussion Paper n. ${ }^{\circ}$ 3021]. Bonn: Zukunft der Arbeit Institute for the Study of Labor.

Cavan, R., Burges, E., Havighurst, R., and Goldhamer, H. (1949). Personal adjustment in old age. Chicago, USA: Science Research Associates.

Cohen-Mansfield, J. (1989). Employment and volunteering roles for the elderly: Characteristics, attributions, and strategies. Journal of Leisure Research, 21(3), 214-227. Retrieved from: https://psycnet.apa.org/record/1990-14486-001. Accessed June 27, 2017.

Cosenza, J. P., Saz Gil, M. I., and Zardoya Alegría, A. I. (2016). Voluntariado Corporativo y Responsabilidad de la Empresa: Aproximación a la Gestión de los Recursos Humanos. Estudos de Administração e Sociedade, 1(1), 67-79. Retrieved from: doi: https://doi.org/10.22409/eas.v1i1.5 Accessed June 27, 2017.

Costa, P. T., and McCrae, R. R. (1980). Still Stable after all these years: personality as a year to some issues in aging. In: Baltes, P. B., and Brim, O. G. (Eds.). Life-Span Development and Behavior, 3. New York, USA: Academic Press.

Cycyota, C. S., Ferrante, C. J., and Schroeder, J. M. (2016). Corporate social responsibility and employee volunteerism: What do the best companies do? Business Horizons, 59, 321-329. Retrieved from: https://doi.org/10.1016/j.bushor.2016.01.004. Accessed June 27, 2017.

Dávila, M. C., and Díaz-Morales, J. F. (2009). Voluntariado y tercera edad. Anales de psicología, 25(2), 375-389. Retrieved from: https://psycnet.apa.org/record/2009-22893-021. Accessed June 27, 2017.

Cosenza, J. P., Gil, M. I. S., \& Alegría, A. I. Z. (2018). Corporate Volunteering: a Tool for Promoting a Strategy for Internal Corporate Social Responsibility Integrating Retirees. Revista Kairós-Gerontologia, 21(4), 161-189. Print ISSN $1516-2567$. ISSNe 2176-901X. São Paulo (SP), Brasil: FACHS/NEPE/PEPGG/PUC-SP 
Di Maggio, P. J., and Powell, W. W. (1983). The iron cage revisited: institutional isomorphism and collective rationality in organizational fields. American Sociological Review, 48(2), 147-160. Retrieved from: 10.2307/2095101. Accessed June 27, 2017.

Eller, H. (2013). Volunteers within an Organizational Context-One Term Is Not Enough. Journal of Business and Economics, 4(9), 895-904. Retrieved from: http://www.academicstar.us/UploadFile/Picture/2014-6/201461485421474.pdf. Accessed June 27, 2017.

Ferreira, P. M. (2015). O Envelhecimento ativo em Portugal: tendências recentes e (alguns) problemas. Revista Kairós-Gerontologia, 18(19), 07-29. São Paulo, SP, Brasil: PUC-SP. Print ISSN 1516-2567. ISSNe 2176-901X. Retrieved from: file://C:/Users/Dados/Downloads/2711371028-1-SM\%20(2).pdf. Accessed June 27, 2017.

Freeman, R. E. (2010). Strategic Management: a Stakeholder Approach. Cambridge: Cambridge University Press.

Gallardo, D., Sánchez, M. I., Corchuelo, M. B., and Guerra, A. (2010). Diagnóstico del voluntariado corporativo en la empresa española. Revista de Estudios Empresariales. Segunda época, 2, 54-80. Retrieved from: file:///C:/Users/Dados/Downloads/474Texto\%20del\%20art\%C3\%ADculo-1605-1-10-20101227.pdf. Accessed June 27, 2017.

Gauthier, A. H., and Smeeding, T. M. (2003). Time use at older ages. Research on Aging, 25(3), 247-274. Retrieved from: http://dx.doi.org/10.1177/0164027503025003003. Accessed June 27, 2017.

Gonyea, J. G., and Googins, B. K. (2006). Expanding the Boundaries of Corporate Volunteerism: Tapping the Skills, Talent, and Energy of Retirees. Generations, 30(4), 78-84. Retrieved from: https://www.ingentaconnect.com/content/asag/gen/2006/00000030/00000004/art00014. Accessed June 27, 2017.

Grant, R. M. (1996). Dirección Estratégica. Conceptos, Técnicas y Aplicaciones. Madrid, España: Civitas.

Greenfield, E. A., and Marks, N. (2004). Formal volunteering as a protective factor for older adults psychological well-being. Journal of Gerontology: Social Sciences, 59B(5), S258-S264. Retrieved from: http://www.midus.wisc.edu/findings/pdfs/147.pdf. Accessed June 27, 2017.

Guerra, A. (2006). Implicación del Sistema Financiero en la Empresa Extremeña. Cáceres: Caja de Ahorros de Extremadura.

Guerra Guerra, A. (2013). Factores explicativos de la práctica de voluntariado corporativo en España. Revista Internacional de Organizaciones, 11, 131-130. Retrieved from: file://C:/Users/Dados/Downloads/Dialnet-FactoresExplicativosDeLaPracticaDeVoluntariado Corp-4994813.pdf. Accessed June 27, 2017.

Guerra Díaz, E. (2016). Falta integrar a jubilados en los programas corporativos de voluntariado. ¿Es más conveniente hacerse voluntario una vez jubilado o iniciar durante la vida activa? ExpokNews-Comunicación de Sustentabilidad y RSC. Retrieved from: http://www.expoknews.com/falta-integrar-a-jubilados-en-los-programas-corporativos-devoluntariado. Accessed July 03, 2016. 
Guterbock, T. M., and Fries, J. C. (1997). Maintaining America's Social Fabric: the AARP Survey of Civic Involvement. Washington, DC: American Association of Retired Persons. Retrieved from: https://www.ncjrs.gov/App/Publications/abstract.aspx?ID=171719. Accessed December 13, 2017.

Hambach, E. (Ed.). (2012). Volunteering infrastructure in Europe. Brussels: European Volunteer Centre.

Havighurst, R. J., Neugarten, B., and Tobin, S.S. (1963). Disengagement, per-sonality and life satisfaction in the later years. In: Hansen, P. (Ed.). Age with a future, 419-425. Copenhagen: Munksgoard.

Havighurst, R., and Albrech, R. (1953). Older people. New York, USA: Longmans, Green.

Herzog, A., Kahn, R. L., Morgan, J. N., Jackson, J. S., and Antonucci, T. C. (1989). Age differences in productive activities. Journal of Gerontology: Social Sciences, 44(4), 129-138. Retrieved from: https://doi.org/10.1093/geronj/44.4.S129. Accessed June 27, 2017.

Hu, J., Jiang, K., Mo, S., Chen, H., and Shi, J. (2016). The motivational antecedents and performance consequences of corporate volunteering: When do employees volunteer and when does volunteering help versus harm work performance? Organizational Behavior and Human Decision Processes, 137, 99-111. Retrieved from: http://dx.doi.org/10.1016/j.obhdp.2016.08.005. Accessed June 27, 2017.

Iacub, R., Machluk, L., Mansinho, M., \& Salamé, M. V. (2015). Dispositivos prejubilatorios como facilitadores del potencial humano. Revista Kairós-Gerontologia, 18(21), 85-97. São Paulo, SP, Brasil: PUC-SP. Print ISSN 1516-2567. ISSNe 2176-901X. Retrieved from: https://revistas.pucsp.br/kairos/article/viewFile/29446/20545. Accessed June 27, 2017.

King, R. R., and Fluke, J. (1990). Volunteers: America's hidden resource. Lanham, MD: University Press.

Krasnopolskaya, I., Roza, L., and Meijs, L. C. P. M. (2016). The Relationship Between Corporate Volunteering and Employee Civic Engagement Outside the Workplace in Russia. Voluntas: International Journal of Voluntary \& Nonprofit Organizations, 27, 640-672. Retrieved from: https://doi.org/10.1007/s11266-015-9599-6. Accessed June 27, 2017.

Lambe, C. J., Wittnann, C. M., and Speakman, R. E. (2001). Social exchange theory and research on business-t-business relational exchange. Journal of Business-to-Business Marketing, 8(3), 1-36. Retrieved from: 10.1300/J033v08n03_01. Accessed June 27, 2017.

Lantos, G. P. (2002). The ethicality of altruistic corporate social responsibility. Journal of Consumer Marketing, 19(3), 205-232. Retrieved from: doi: https://doi.org/10.1108/07363760210426049. Accessed June 27, 2017.

Lawson, D. (1993). Dar para vivir, cómo el dar puede cambiar su vida. México: Ed. Diana.

Lee, Y., and Brudney, J. L. (2009). Rational volunteering: a benefit-cost approach. International Journal of Sociology and Social Policy, 29(9/10), 512-530. Retrieved from: doi: https://doi.org/10.1108/01443330986298. Accessed June 27, 2017.

Lima, A. J., and Bareli, P. (2011). A importância Social do Desenvolvimento do Trabalho Voluntário. Retrieved from: www.eticaempresarial.com.br/imagens.../File/.../artigo_voluntariado.pdf. Accessed April 13, 2014.

Cosenza, J. P., Gil, M. I. S., \& Alegría, A. I. Z. (2018). Corporate Volunteering: a Tool for Promoting a Strategy for Internal Corporate Social Responsibility Integrating Retirees. Revista Kairós-Gerontologia, 21(4), 161-189. Print ISSN $1516-2567$. ISSNe 2176-901X. São Paulo (SP), Brasil: FACHS/NEPE/PEPGG/PUC-SP 
Lum, T. Y., and Lightfoot, E. (2005). The effects of volunteering on the physical and mental health of older people. Research on Aging, 27(1), 31-55. Retrieved from: 10.1177/0164027504271349. Accessed June 27, 2017.

Luoh, M. C., and Herzog, A. R. (2002). Individual consequences of volunteer and paid work in old age: health and mortality. Journal of Health and Social Behaviour, 43(4), 490-509. Retrieved from: https://www.ncbi.nlm.nih.gov/pubmed/12664678. Accessed June 27, 2017.

Maddox, G. L. and Douglas, E. B. (1973). Self-assessment of health: A longitudinal study of elderly subjects. Journal of Health and Social Behavior, 14(1), 87-93. Retrieved from: 10.2307/2136940. Accessed June 27, 2017.

Maddox, G. L. (1963). Activity and morale: a longitudinal study of selected elderly subjects. Social Forces, 42(2), 195-201. Retrieved from: doi: 10.2307/2575692. Accessed June 27, 2017.

Mc Donough, W., and Braungart, M. (2002). Design for the Triple Top Line: New Tools for Sustainable Commerce. Corporate Environmental Strategy, 9(3), 251-258. Retrieved from: https://www.globalcommunity.org/business/Design\%20for\%20the\%20Triple\%20Top\%20Line.p df. Accessed June 27, 2017.

Moreno Manrique, V. C. (2013). El voluntariado desde la empresa. Cuadernos de la Cátedra "la Caixa” de Responsabilidad Social de la Empresa y Gobierno Corporativo, 20. Septiembre, IESE Business School. Universidad de Navarra.

Musick, M. A., and Wilson, J. (2003). Volunteering and depression: The role of psychological and social resources in different age groups. Social Science \& Medicine, 56(2), 259-269. Retrieved from: https://www.ncbi.nlm.nih.gov/pubmed/12473312. Accessed June 27, 2017.

Naciones Unidas (1991). Resolución 46/91. Ejecución del Plan de Acción Internacional sobre el Envejecimiento y actividades conexas. Naciones Unidas: Nueva York, 16 de diciembre.

Naciones Unidas. (2003). Declaración Política y Plan de Acción Internacional de Madrid sobre el Envejecimiento, Segunda Asamblea Mundial sobre el Envejecimiento. Madrid, España, 8 a 12 de abril de 2002. Naciones Unidas: Nueva York.

Oddone, M. J. (2010). La teoría social del envejecimiento. un análisis histórico. In: Barca, R. (Comp.). La gerontología a través de una historia institucional. Buenos Aires, Argentina: Centro de Día, 50-62.

Oddone, M. J. (2013). Antecedentes teóricos del Envejecimiento Activo. Informes Envejecimiento en red, 4, 1-9. Retrieved from: http://envejecimiento.csic.es/documentos/ documentos/oddone-antecedentes.pdf. Accessed June 08, 2018.

Peloza, J., and Hassay, D. N. (2006). Intra-organizational volunteerism: good soldiers, good deeds and good politics. Journal of Business Ethics, 64(4), 357-379. Retrieved from: https://doi.org/10.1007/s10551-005-5496-Z. Accessed June 27, 2017.

Pevnaya, M., and Kuzminchuk, A. (2016). Corporate Volunteering in Personnel Development of Russian Companies. Paper presented at 10th International Days of Statistics and Economics, Prague, September 8-10, 2016, 1437-1444. Retrieved from: https://msed.vse.cz/msed_2016/article/189- Pevnaya-Maria-paper.pdf. Accessed June 08, 2018.

Penrose, E. T. (1959). The Theory of the Growth of the Firm. Oxford: Oxford University Press. 
Pérez, M. J., Poyatos, J. A., Bosioc, D., Civico, G., Khan, K., and Loro, S. (2014). Employee volunteering and employee volunteering in humanitarian AID in Europe. Retrieved from: http://ec.europa.eu/echo/files/euaidvolunteers/EUAV_Study_Employee_Volunteering_Europe_F INAL_en.pdf. Accessed June 28, 2017.

Piacentini, P. (2015). Trabalho voluntário no Brasil: parcela pequena da sociedade se engaja nesse tipo de iniciativa. Retrieved from: http://pre.univesp.br/trabalho-voluntario-nobrasil\#.V3x05bgrLIU. Accessed June 03, 2018.

Porter, M. E. (1980). Competitive Strategy. New York, USA: Free Press.

Porter, M. E., and Kramer, M. R. (2002). The Competitive Advantage of Corporate Philanthropy. Harvard Business Review, 80, 57-68. Reprint R0212D Retrieved from: https://www.sharedvalue.org/sites/default/files/resource-files/Competitive_Advantage.pdf. Accessed. November 18, 2017.

Porter, M. E., and Kramer, M. R. (2006). Strategy and society: the link between competitive advantage and corporate social responsibility. Harvard Business Review, 84(12), 78-92. Retrieved from: https://hbr.org/2006/12/strategy-and-society-the-link-between-competitiveadvantage-and-corporate-social-responsibility. Accessed June 27, 2017.

Rosenfeld, S. I., Muterle, M. C., and Gaspar, J. A. (2013). Programa de voluntariado empresarial: reflexões sobre o caso da TRANSPETRO em São Sebastião. Trabajo presentado en el ADM 2013, Congreso Internacional de Administración, Ponta Grossa, PR, 23-27/09/2013.

Rumelt, R. (1984). Toward a strategic theory of the firm. In: Lamb, R. (Ed.). Competitive Strategic Management. New York, USA: Englewood Cliffs: Prentice-Hall.

Sanchez Hernandez, M. I., and Gallardo Vázquez, D. (2013). Approaching corporate volunteering in Spain. Corporate Governance: The International Journal of Business in Society, 13(Issue 4), 397-411. Retrieved from: https://doi.org/10.1108/CG-02-2012-0009. Accessed June 27, 2017.

Santos, P. G., and Fernández Fernández, J. L. (2017). Strategies for corporate volunteer programs. Universia Business Review, Third Quarter 2017, 1698-5117. Retrieved from: 10.3232/UBR.2017.V14.N3.02. Accessed June 27, 2017.

Simon, H. A. (1947). Administrative Behavior. A study of decision-making processes in administrative organization. New York, USA: The Macmillan Co.

Scott, W. R. (1992). Organizations: Rational, natural and open systems. (3rd ed.). Englewood Cliffs: Prentice-Hall.

Souza, S. A. (2008). Educação, trabalho voluntário e responsabilidade social da empresa: "amigos da escola" e outras formas de participação. Doctoral Thesis. São Paulo: USP. Retrieved from: 10.11606/T.48.2008.tde-16062008-103840. Accessed June 27, 2017.

Suchamn, M. C. (1995). Managing legitimacy strategic and institutional approach. Academy of Management Journal, 20(3), 571-610. Retrieved from: http://www.jstor.org/stable/258788. Accessed June 27, 2017. 
Tang, F., Morrow-Howell, N., and Hong, S. (2009). Inclusion of diverse older populations in volunteering: the importance of institutional facilitation. Nonprofit and Voluntary Sector Quarterly, 38(5), 810-827. Retrieved from: http://citeseerx.ist.psu.edu/viewdoc/download?doi= 10.1.1.885.3204\&rep=rep1\&type=pdf. Accessed June 27, 2017.

Vargas, J. G. (2005). Análisis de fundamentos de la Teoría Institucional. Revista Digital Universitaria, 6(8), 1-21. Retrieved from: http://www.revista.unam.mx/vol.6/num8/art84/ ago_art84.pdf. Accessed April 13, 2018.

van Willigen, M. (2000). Differential benefits of volunteering across the life course. Journal of Gerontology Social Sciences, 55B(5), S308-S318. Retrieved from: http://citeseerx.ist.psu.edu/viewdoc/download?doi= 10.1.1.522.2117\&rep=rep1\&type=pdf. Accessed June 27, 2017.

Waikayi, L., Fearon, C., Morris, L., and McLaughlin, H. (2012). Volunteer management: an exploratory case study within the British Red Cross. Management Decision, 50(3), 349-367. Retrieved from: https://pureportal.coventry.ac.uk/en/publications/volunteer-management-anexploratory-case-study-within-the-british. Accessed June 27, 2017.

Warburton, J., Paynter, J., and Petriwskyj, A. (2007). Volunteering as a productive aging activity: incentives and barriers to volunteering by Australian seniors. Journal of Applied Gerontology, 26(4), 333-354. Retrieved from: https://doi.org/10.1177/0733464807304568. Accessed June 27, 2017.

Recebido em 29/09/2018

Aceito em 30/12/2018

José Paulo Cosenza - Doutor em Contabilidade e Finanças pela Universidad de Zaragoza. Espanha. Professor Titular do Programa de Pós-Graduação em Administração, Universidade Federal Fluminense (PPGAd-UFF).

E-mail: jpcosenza@id.uff.br

María Isabel Saz Gil - Doutora pela Universidad de Valencia. Espanha. Professora do Departamento de Direção e Organização de Empresas, Universidad de Zaragoza. Espanha. E-mail: sazgil@unizar.es 
Ana Isabel Zardoya Alegría - Doutora em Ciências Empresariais pela Universidad de Zaragoza. Professora Titular do Departamento de Contabilidade e Finanças, Universidad de Zaragoza. Espanha.

E-mail: azardoya@unizar.es 